\title{
Pengaruh Ketiadaan Inang terhadap Tanggap Reproduksi Trichogrammatoidea armigera Nagaraja dan Trichogramma japonicum Ashmed (Hymenoptera: Trichogrammatoidea) dan Implikasinya terhadap penerimaan Inang
}

\author{
ANIS ROHMANI ${ }^{1)}$, DAMAYANTI BUCHORI ${ }^{2)}$, ADHA SARI ${ }^{2)}$ \\ ${ }^{1)}$ Alumnus S1 Departemen Proteksi Tanaman, Fakultas Pertanian, \\ Institut Pertanian Bogor \\ ${ }^{2)}$ Departemen Proteksi Tanaman, Fakultas Pertanian, \\ Institut Pertanian Bogor
}

(diterima Mei 2008, disetujui Agustus 2008)

\begin{abstract}
Effect of Host Deprivation toward Reproductive Capacity of Trichogrammatoidea armigera dan Trichogramma japonicum and Its Implication on Host Acceptance. Trichogrammatoidea armigera and Trichogramma japonicum are polyphagous egg parastioids, that are important as natural enemies. The objective of this research was to study the effect of host deprivation on reproductive capacity of $T$. armigera and $T$. japonicum. . This study consists of 8 treatments, host deprivation : 0 hour, 1 hour, 2 hours, 3 hours, 6 hours, 12 hours, and 48 hours. Host were replaced every 24 hours. Results showed there are difference with respect of how the two parasitoids respond to the treatment. Deprivation of host for 3 hours in T. armigera resulted in the increase of egg production and parasitism rate. After 12 and 24 hours of not encountering any hosts, the numbers of eggs produced drastically decreased. Treatment on $T$. japonicum resulted in the reaction of fecundity and parasitism rate overall. Forty eight hours of host deprivation resulted in death of both parasitoids species within 2 days. None of the parasitoids seems to produce any egg.
\end{abstract}

KEY WORDS: Host deprivation, Trichogrammatoidea armigera, Trichogramma japonicum, oosorption.

\section{PENDAHULUAN}

Keberhasilan reproduksi parasitoid dipengaruhi oleh beberapa faktor, antara lain tipe parasitoid, umur parasitoid, nisbah kelamin dan ketersediaan inang. Parasitoid proovigenik yang memiliki telur matang pada saat kemunculan imago, oviposisi dapat langsung dilakukan segera setelah kemunculannya, sedangkan parasitoid tipe sinovigenik harus memproduksi telur terlebih dulu sebelum melakukan oviposisi. Parasitoid yang memulai oviposisi pada saat masih muda memiliki kemampuan oviposisi yang lebih tinggi daripada parasitoid yang 
tua, karena memiliki pengalaman dalam melakukan oviposisi pada awal kehidupannya (Drost \& Cardé 1992). Pengaruh nisbah kelamin terhadap keberhasilan reproduksi adalah bila jumlah imago betina lebih besar maka kemampuan reproduksi populasi tersebut tinggi. Demikian juga ketersediaan inang, semakin banyak inang yang ditemukan maka semakin besar kesempatan parasitoid untuk melakukan oviposisi.

Pada beberapa jenis parasitoid, betina yang tidak dapat menemukan inang pada periode waktu tertentu akan menyerap kembali sejumlah telur yang telah terdapat dalam ovarinya. Namun tidak semua parasitoid memiliki kemampuan mengabsorpsi telur-telurnya. Parasitoid yang mampu mengabsorbsi telur biasanya parasitoid yang termasuk tipe sinovigenik, yaitu parasitoid yang memproduksi telur selama hidupnya. Sedangkan parasitoid proovigenik, yang memiliki telur pada saat memasuki stadia imago biasanya tidak mempunyai kemampuan menyerap telurnya kembali (Quicke 1997). Sejauh ini belum diperoleh informasi mengenai kemampuan Trichogrammatoidea armigera dan Trichogramma japonicum untuk menyerap kembali telurtelur dalam ovari. Oleh karena itu dilakukan penelitian untuk mengetahui pola pematangan telur dan kemampuan mengabsorbsi kembali telur-telur dari T. armigera dan $T$. japonicum.
Penelitian ini bertujuan mengetahui pengaruh ketiadaan inang terhadap tanggap reproduksi $T$. armigera dan $T$. japonicum serta implikasinya terhadap penerimaan inang.

\section{BAHAN DAN METODE}

\section{Pelaksanaan Penelitian}

Penelitian dilaksanakan di Laboratorium Bioekologi Predator dan Parasitoid, Departemen Proteksi Tanaman, Fakultas Pertanian, Insitut Pertanian Bogor, sejak bulan Februari hingga Juni 2001. Penelitian ini tersusun dalam Rancangan Acak Lengkap dengan 8 perlakuan ketiadaan inang, selama $0,1,2,3,6,12,24$ dan 48 jam. Setiap perlakuan diulang sebanyak 10 kali. T. japonicum dan $T$. armigera yang keluar dari inang dibiarkan tidak diberi inang selama 0 , 1, 2, 3, 6, 12, 24 dan 48 jam. Setelah periode ketiadaan inang, $T$. japonicum dan $T$. armigera diberi inang (50 telur C. cephalonica) sampai imago mati dan inang diganti dengan yang baru setiap 24 jam. Untuk mengetahui sisa telur dalam ovari, dilakukan pembedahan setelah imago mati dan dihitung sisa telurnya. Sebagai pembanding, terdapat kelompok parasitoid yang mendapat perlakuan yang sama tetapi dibedah segera setelah perlakuan. Sebanyak 10 ulangan. Pembedahan dimaksudkan untuk menghitung jumlah telur di dalam ovari. 
Pengamatan dilakukan terhadap:

1. Persentase Parasitisasi dihitung dengan rumus:

Parasitisasi $(\%)=\frac{\text { Jumlah telur terparasit }}{\text { Jumlah total telur }} \times 100 \%$

2. Jumlah telur dalam ovari

Untuk menghitung sisa telur dalam ovari dilakukan pembedahan.

3. Lama hidup imago betina

\section{HASIL DAN PEMBAHASAN}

\section{Pengaruh Ketiadaan Inang}

Terhadap Parasitisasi T. armigera

Ketiadaan inang mempengaruhi parasitisasi $(\mathrm{P}=0,0000)$, peletakan telur $(\mathrm{P}=0,0237)$, keperidian $(\mathrm{P}=0,0017)$, produksi telur $(\mathrm{P}=0,0017)$ dan lama hidup $(\mathrm{P}=0,0090) \quad T$. armigera. Ketiadaan inang mempunyai pengaruh yang berbeda terhadap parasitisasi dan produksi telur. Ketiadaan inang sampai dengan 3 jam ternyata meningkatkan parasitisasi dan jumlah telur yang dihasilkan. Tapi ketiadaan inang yang terlalu lama (12 jam) ternyata menurunkan kemampuan parasitisasi dan produksi telur. Jumlah telur yang tersisa dalam ovari meningkat dengan makin lamanya $T$. armigera tidak menemukan inang (Tabel 1).

Peletakan telur pada hari pertama meningkat pada parasitoid yang tidak mendapat inang selama 2 dan 3 jam. Hal ini terlihat dari peningkatan jumlah telur yang diletakkan dari 34,3 butir telur pada perlakuan inang langsung diberikan menjadi 41,6 butir pada perlakuan 3 jam tanpa inang. Penurunan jumlah telur yang diletakkan pada hari pertama terjadi pada perlakuan 12 jam tanpa inang menjadi 24,3 butir, demikian juga pada perlakuan tanpa inang selama 24 jam jumlah telur yang diletakkan menjadi 18,7 butir (Tabel 1). Pembedahan yang dilakukan terhadap imago betina segera setelah perlakuan menunjukkan bahwa imago betina $T$. armigera memiliki telur dalam ovari sebanyak 20,5 butir pada awal kemunculannya menjadi imago. Jumlah telur dalam ovari meningkat selama 3 jam menjadi 37,0 butir, dan mulai menurun menjadi 28,5 butir setelah 12 jam tidak menemukan inang. Di hari kedua, peletakan telur $T$. armigera tidak dipengaruhi oleh ketiadaan inang ( $\mathrm{P}=0,186)$. Imago $T$. armigera meletakkan telur dalam jumlah yang lebih sedikit daripada peletakan hari pertama dan mengalami kematian pada perlakuan 12 jam tanpa inang. (Tabel 1)

Keperidian $T$. armigera menurun setelah 12 jam tidak menemukan inang. Keperidian dan potensi produksi telur $T$. armigera meningkat sampai 3 jam pertama setelah muncul, dan selanjutnya menurun sampai $T$. armigera mati (Tabel 2). 
Tabel 1. Jumlah telur dalam ovari, diletakkan setelah 24, 48 jam, keperidian dan persentase parasitisasi $T$. armigera selama 24 jam pertama setelah perlakuan

\begin{tabular}{|c|c|c|c|c|c|}
\hline \multirow[b]{2}{*}{$\begin{array}{l}\text { Perlakuan } \\
\text { (Jam) }\end{array}$} & \multicolumn{5}{|c|}{$\begin{array}{lll}\text { Jumlah telur (butir) } & \mathrm{X} \pm \mathrm{SD} \\
\end{array}$} \\
\hline & $\begin{array}{l}\text { Dalam ovari setelah } \\
\text { perlakuan }\end{array}$ & $\begin{array}{l}\text { Diletakkan selama } \\
24 \text { jam (Hari ke-1) }\end{array}$ & $\begin{array}{l}\text { Diletakkan } \\
\text { selama } 48 \text { jam } \\
\text { (Hari ke-2) }\end{array}$ & Keperidian & $\begin{array}{l}\text { Parasitisasi selama } \\
24 \text { jam pertama (\%) }\end{array}$ \\
\hline 0 & $20,5 \pm 6,5 \mathrm{fg}$ & $34,3 \pm 4,6 \mathrm{bc}$ & $3,5 \pm 5,8 \mathrm{ab}$ & $37,8 \pm 7,0 \mathrm{ab}$ & $68,4 \pm 7,3 \mathrm{a}$ \\
\hline 1 & $20,4 \pm 1,7 \mathrm{fg}$ & $40,3 \pm 4,7 \mathrm{ab}$ & $3,7 \pm 6,0 \mathrm{ab}$ & $44,0 \pm 7,7 \mathrm{bc}$ & $74,4 \pm 8,4 \mathrm{ab}$ \\
\hline 2 & $37,8 \pm 9,7 \mathrm{bc}$ & $41,5 \pm 9,7 \mathrm{a}$ & $3,1 \pm 6,5 \mathrm{ab}$ & $44,6 \pm 12,2 b$ & $75,8 \pm 19,7 \mathrm{ab}$ \\
\hline 3 & $37,0 \pm 10,8 \mathrm{ab}$ & $41,6 \pm 2,5 \mathrm{a}$ & $5,3 \pm 7,1 \mathrm{a}$ & $46,9 \pm 6,5 b$ & $79,4 \pm 6,3 \mathrm{~b}$ \\
\hline 6 & $33,2 \pm 11,4 \mathrm{bcd}$ & $33,6 \pm 9,1 b c$ & $1,8 \pm 4,0 a b$ & $35,4 \pm 6,8 \mathrm{~b}$ & $70,0 \pm 15,7 \mathrm{ab}$ \\
\hline 12 & $28,5 \pm 9,3 \mathrm{cde}$ & $24,3 \pm 8,6 \mathrm{efg}$ & $0,0 \pm 0,0 \mathrm{c}$ & $24,3 \pm 8,6 \mathrm{~d}$ & $49,5 \pm 17,1 \mathrm{c}$ \\
\hline 24 & $26,5 \pm 10,8 \mathrm{def}$ & $18,7 \pm 4,6 \mathrm{~g}$ & $0,0 \pm 0,0 \mathrm{c}$ & $18,7 \pm 4,6 \mathrm{~d}$ & $38,8 \pm 6,7 \mathrm{c}$ \\
\hline 48 & $0,0 \pm 0,0 \mathrm{~h}$ & $0,0 \pm 0,0 \mathrm{~h}$ & $3,5 \pm 5,8 \mathrm{ab}$ & $37,8 \pm 7,0 \mathrm{ab}$ & $0,0 \pm 0,0 \mathrm{~d}$ \\
\hline
\end{tabular}

Tabel 2. Total keperidian dan potensi produksi telur T. armigera

\begin{tabular}{cccc}
\hline \hline $\begin{array}{c}\text { Perlakuan } \\
(\text { jam) }\end{array}$ & Keperidian (butir) $\mathrm{X} \pm \mathrm{SD}$ & $\begin{array}{c}\text { Sisa telur dalam ovari } \\
\text { (butir) } \mathrm{X} \pm \mathrm{SD}\end{array}$ & $\begin{array}{c}\text { Potensi produksi (butir) } \\
\mathrm{X} \pm \mathrm{SD}\end{array}$ \\
\hline 0 & $37,8 \pm 7,0 \mathrm{ab}$ & $2,4 \pm 2,8 \mathrm{a}$ & $40,2 \pm 8,4 \mathrm{bc}$ \\
1 & $44,0 \pm 7,7 \mathrm{bc}$ & $0,7 \pm 0,8 \mathrm{~b}$ & $44,7 \pm 7,7 \mathrm{ab}$ \\
2 & $44,6 \pm 12,2 \mathrm{~b}$ & $1,2 \pm 1,0 \mathrm{ab}$ & $45,8 \pm 12,5 \mathrm{ab}$ \\
3 & $46,9 \pm 6,5 \mathrm{~b}$ & $0,7 \pm 1,0 \mathrm{~b}$ & $47,6 \pm 4,8 \mathrm{a}$ \\
6 & $35,4 \pm 6,8 \mathrm{~b}$ & $0,4 \pm 0,7 \mathrm{~b}$ & $35,8 \pm 7,0 \mathrm{c}$ \\
12 & $24,3 \pm 8,6 \mathrm{~d}$ & $1,0 \pm 1,0 \mathrm{~b}$ & $25,3 \pm 8,2 \mathrm{~d}$ \\
24 & $18,7 \pm 4,6 \mathrm{~d}$ & $1,1 \pm 1,4 \mathrm{~b}$ & $19,8 \pm 4,4 \mathrm{~d}$ \\
48 & $0,0 \pm 0,0 \mathrm{e}$ & $0,0 \pm 0,0 \mathrm{~b}$ & $0,0 \pm 0,0 \mathrm{e}$ \\
\hline
\end{tabular}

Angka diikuti huruf sama pada lajur yang sama tidak berbeda pada uji Duncan 0,05

\section{Pengaruh Ketiadaan Inang Terhadap Parasitisasi $T$. japonicum}

Ketiadaan inang tidak mempengaruhi parasitisasi $T$. japonicum pada hari pertama $(\mathrm{P}=0,137)$ tetapi mempengaruhi jumlah telur yang diletakkan pada hari pertama $(\mathrm{P}=0,024)$, dan hari kedua $(\mathrm{P}=0,012)$, keperidian $(\mathrm{P}=0,002)$ dan produksi telur $(\mathrm{P}=0,000)$. Perbedaan parasitisasi yang dilakukan pada hari pertama tidak nyata antara imago yang menemukan inang segera setelah muncul dengan imago yang baru menemukan inang setelah 24 jam. Telur T. japonicum yang diletakkan pada hari pertama berkisar antara 35-41 butir untuk semua perlakuan. Jumlah telur dalam ovari setelah perlakuan cenderung menurun sejalan dengan semakin lamanya imago tidak menemukan inang. Pada awal kemunculan menjadi imago, T. japonicum memiliki telur dalam ovari sebanyak 30,9 butir dan menurun setelah 6 jam tidak menemukan inang menjadi 19,5 butir, demikian juga pada perlakuan 24 jam tanpa inang jumlah telur menurun menjadi 17,2 butir saja (Tabel 3). Keperidian dan potensi produksi telur 
Tabel 3. Jumlah telur dalam ovari, diletakkan setelah 24, 48, 72 jam, keperidian dan persentase parasitisasi $T$. japonicum selama 24 jam pertama setelah perlakuan

\begin{tabular}{|c|c|c|c|c|c|c|}
\hline \multirow[b]{2}{*}{$\begin{array}{l}\text { Perlakuan } \\
\text { (jam) }\end{array}$} & \multicolumn{6}{|c|}{ Jumlah telur (butir) $\mathrm{X} \pm \mathrm{SD}$} \\
\hline & $\begin{array}{l}\text { Dalam ovari } \\
\text { setelah perlakuan }\end{array}$ & $\begin{array}{l}\text { Diletakkan } \\
\text { selama } 24 \text { jam } \\
(\text { Hari ke-1) }\end{array}$ & $\begin{array}{l}\text { Diletakkan } \\
\text { selama } 48 \text { jam } \\
(\text { Hari ke-2) } \\
\end{array}$ & $\begin{array}{l}\text { Diletakkan } \\
\text { selama } 72 \text { jam } \\
(\text { Hari ke-3) } \\
\end{array}$ & Keperidian & $\begin{array}{l}\text { Parasitisasi selama } \\
24 \text { jam pertama } \\
(\%)\end{array}$ \\
\hline 1 & $28,2 \pm 7,6 \mathrm{cde}$ & $40,3 \pm 4,7 \mathrm{a}$ & $7,6 \pm 8,4 \mathrm{ab}$ & $1,0 \pm 1,8 \mathrm{ab}$ & $48,9 \pm 9,9 \mathrm{a}$ & $73,6 \pm 8,4 \mathrm{ab}$ \\
\hline 2 & $23,8 \pm 8,7$ def & $31,3 \pm 7,2 \mathrm{bc}$ & $2,8 \pm 4,5 \mathrm{c}$ & $0,0 \pm 0,0 \mathrm{c}$ & $34,1 \pm 7,2 \mathrm{c}$ & $67,7 \pm 12,2 \mathrm{a}$ \\
\hline 12 & $20,0 \pm 10,2 \mathrm{f}$ & $38,7 \pm 6,3 \mathrm{a}$ & $3,0 \pm 4,9 \mathrm{bc}$ & $0,0 \pm 0,0 \mathrm{c}$ & $41,7 \pm 4,3 b$ & $78,5 \pm 11,9 b$ \\
\hline 24 & $17,2 \pm 5,0 \mathrm{f}$ & $39,8 \pm 4,1 \mathrm{a}$ & $0,0 \pm 0,0 \mathrm{c}$ & $0,0 \pm 0,0 \mathrm{c}$ & $39,8 \pm 4,1 \mathrm{bc}$ & $73,8 \pm 10,7 \mathrm{ab}$ \\
\hline 48 & $0,0 \pm 0,0 \mathrm{~g}$ & $0,0 \pm 0,0 \mathrm{~g}$ & $0,0 \pm 0,0 \mathrm{c}$ & $0,0 \pm 0,0 \mathrm{c}$ & $0,0 \pm 0,0 \mathrm{~d}$ & $0,0 \pm 0,0 \mathrm{c}$ \\
\hline
\end{tabular}

Angka diikuti huruf sama pada lajur yang sama tidak berbeda pada uji Duncan 0,05

Tabel 4. Total keperidian dan potensi produksi telur T. japonicum

\begin{tabular}{llll}
\hline \hline $\begin{array}{l}\text { Perlakuan } \\
\text { (jam) }\end{array}$ & $\begin{array}{l}\text { Keperidian (butir) } \\
\mathrm{X} \pm \mathrm{SD}\end{array}$ & $\begin{array}{l}\text { Sisa telur dalam ovari } \\
\text { (butir) } \mathrm{X} \pm \mathrm{SD}\end{array}$ & $\begin{array}{l}\text { Potensi produksi } \\
\text { (butir) } \mathrm{X} \pm \mathrm{SD}\end{array}$ \\
\hline 0 & $44,5 \pm 10,9 \mathrm{ab}$ & $0,5 \pm 1,0 \mathrm{ab}$ & $45,0 \pm 10,5 \mathrm{ab}$ \\
1 & $48,9 \pm 9,9 \mathrm{a}$ & $1,1 \pm 1,1 \mathrm{a}$ & $50,0 \pm 10,0 \mathrm{a}$ \\
2 & $34,1 \pm 7,2 \mathrm{c}$ & $0,7 \pm 1,0 \mathrm{ab}$ & $34,8 \pm 7,2 \mathrm{c}$ \\
3 & $38,9 \pm 5,3 \mathrm{bc}$ & $1,0 \pm 1,0 \mathrm{a}$ & $39,9 \pm 9,9 \mathrm{bc}$ \\
6 & $42,7 \pm 5,9 \mathrm{~b}$ & $1,0 \pm 1,0 \mathrm{a}$ & $43,7 \pm 6,1 \mathrm{ab}$ \\
12 & $41,7 \pm 4,3 \mathrm{~b}$ & $0,8 \pm 0,9 \mathrm{ab}$ & $42,5 \pm 4,9 \mathrm{~b}$ \\
24 & $39,8 \pm 4,1 \mathrm{bc}$ & $1,0 \pm 1,0 \mathrm{a}$ & $40,8 \pm 4,3 \mathrm{bc}$ \\
48 & $0,0 \pm 0,0 \mathrm{~d}$ & $0,0 \pm 0,0 \mathrm{~b}$ & $0,0 \pm 0,0 \mathrm{~d}$ \\
\hline
\end{tabular}

Angka diikuti huruf sama pada lajur yang sama tidak berbeda pada uji Duncan 0,05

$T$. japonicum cenderung menurun dengan adanya perlakuan ketiadaan inang. $\quad T$. japonicum meletakkan hampir semua telurnya dan hanya menyisakan telurnya dalam ovari dalam jumlah yang sedikit (Tabel 4).

\section{Lama Hidup Imago}

Imago $T$. armigera hidup paling lama pada perlakuan inang diberikan setelah 24 jam (2 hari), sedangkan $T$. japonicum hidup lebih lama pada perlakuan inang yang diberikan setelah 6 jam (2,25 hari) (Gambar 1). $T$. japonicum dan $T$. armigera mengalami kematian setelah 48 jam tidak menemukan inang. Dari pembedahan yang dilakukan pada imago yang mati tanpa melakukan oviposisi, tidak ditemukan telur dalam ovarinya.

\section{Trichogramatoidea armigera} memiliki sejumlah telur pada saat muncul menjadi imago. Jumlah telur ini meningkat selama 3 jam pertama walaupun tidak menemukan inang yang semula 20,5 butir menjadi 37,0 butir (Tabel 1). Peningkatan jumlah telur ini mungkin disebabkan oleh adanya produksi telur yang masih terus berlangsung sehingga jumlah telur 


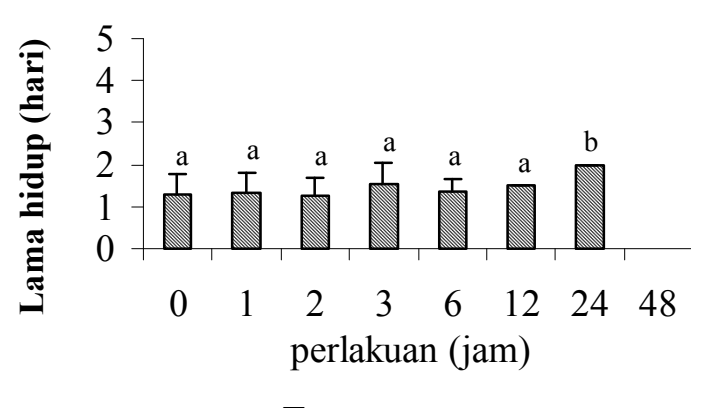

T. armigera

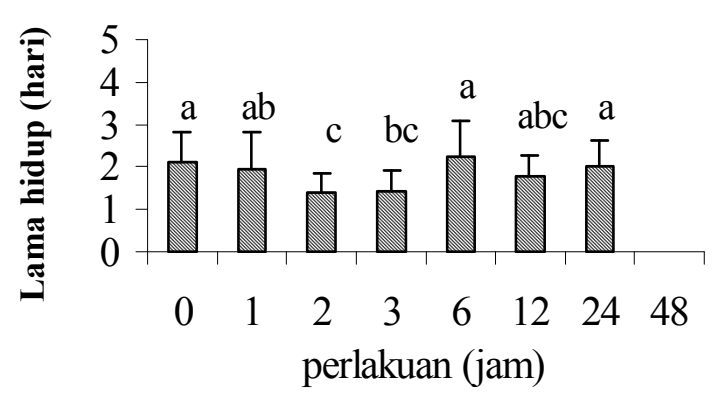

T.japonicum

Gambar 1. Pengaruh ketiadaan inang terhadap lama hidup T. armigera dan $T$. japonicum

dalam ovari bertambah banyak. Pada perlakuan tanpa inang selama 12 jam dan 24 jam jumlah telur dalam ovari menjadi lebih sedikit daripada jumlah telur dalam ovari pada saat baru muncul menjadi imago. Penurunan ini mungkin disebabkan oleh adanya penyerapan kembali telur-telur dalam ovari yang tidak diletakkan bila inang tidak ditemukan (Flanders 1958 dalam Quicke 1997).

Jumlah telur yang diletakkan juga meningkat dengan adanya perlakuan ketiadaan inang selama 3 jam pertama, namun menurun bila imago tidak menemukan inang selama 12 jam dan 24 jam. Peningkatan dan penurunan jumlah telur yang diletakkan berkaitan dengan jumlah telur dalam ovari sebelum melakukan peletakan telur pada inang. Jumlah telur dalam ovari menunjukkan potensi yang dimiliki imago untuk melakukan oviposisi. Semakin banyak jumlah telur dalam ovari, semakin banyak telur yang mampu diletakkan.

Pemberian inang dapat menstimulasi peningkatan produksi telur. Hal ini terlihat pada jumlah telur yang diletakkan yang cenderung lebih banyak daripada jumlah telur sebelum pemberian inang. Pengaruh pemberian inang terhadap peningkatan produksi telur hanya berlangsung sampai 3 jam tanpa inang. Pada perlakuan 6 jam tanpa inang tidak terjadi peningkatan produksi telur yang nyata. Pada perlakuan 12 jam dan 24 jam tanpa inang tidak menyebabkan peningkatan produksi telur, hal ini terlihat dari jumlah telur dalam ovari setelah perlakuan yang lebih banyak daripada jumlah telur yang diletakkan. Peningkatan produksi yang terjadi pada imago $T$. armigera kemungkinan disebabkan oleh adanya pemberian inang yang dapat menstimulasi produksi telur parasitoid, seperti diungkapkan oleh Drost \& Cardé 
(1992) bahwa pemberian inang dapat menyebabkan peningkatan produksi telur. Penurunan jumlah telur yang diletakkan oleh $T$. armigera pada perlakuan 12 jam dan 24 jam tanpa inang mungkin disebabkan oleh adanya penyerapan telur-telur dalam ovari yang terus berlangsung atau lamanya imago tidak menemukan inang sehingga parasitoid tidak berpengalaman dalam melakukan parasitisasi. Penyerapan telur yang terjadi pada imago $T$. armigera digunakan sebagai tambahan nutrisi untuk mempertahankan hidup dan sebagai sumber energi untuk melakukan oviposisi (Godfray 1994).

Parasitisasi yang dilakukan $T$. armigera pada hari pertama meningkat sampai 3 jam setelah kemunculan imago yaitu dari $68,47 \%$ menjadi $79,46 \%$ dan menurun menjadi $49,52 \%$ setelah 12 jam tidak menemukan inang untuk oviposisi (Tabel 1). Peningkatan parasitisasi ini mungkin disebabkan oleh adanya produksi telur yang masih terus berlangsung sehingga jumlah telur dalam ovari mejadi banyak dan hal ini menyebabkan peningkatan laju penerimaan inang oleh $T$. armigera. Penerimaan inang ditandai dengan adanya parasitisasi pada inang dan laju penerimaan inang sebanding dengan tingkat parasitisasi yang terjadi (Li et. al. 1994). Parasitisasi T. armigera yang tinggi pada hari pertama menemukan inang menunjukkan bahwa penerimaan inang parasitoid tersebut berjalan dengan baik. Penurunan parasitisasi $T$. armigera pada perlakuan 12 jam tanpa inang mungkin karena jumlah telur dalam ovari yang sedikit sehingga jumlah peletakan telur juga sedikit. Penurunan parasitisasi ini mungkin juga disebabkan karena tidak ditemukannya inang dalam waktu yang cukup lama sehingga parasitoid tidak mempunyai pengalaman dalam pemarasitan seperti yang diungkapkan oleh Drost \& Cardé (1992) bahwa pemuasaan parasitoid pada awal parasitisasi menyebabkan penurunan parasitisasi karena belum adanya pembelajaran dan pengalaman dalam oviposisi.

Imago Trichogramma japonicum mempunyai telur dalam ovari sebanyak 30,9 butir pada awal kemunculannya menjadi imago, jumlah telur ini menurun menjadi 19,5 butir apabila 6 jam tidak menemukan inang dan menjadi 17,2 butir setelah 24 jam tanpa inang (Tabel 4). Berkurangnya telur dalam ovari diduga karena adanya penyerapan telur dalam ovari yang terjadi seperti pada $T$. armigera. Penyerapan telur dalam ovari yang terjadi pada imago $T$. japonicum terjadi sebelum imago menemukan inang. Semakin lama imago tidak menemukan inang semakin banyak telur yang diserap kembali. Walaupun jumlah telur semakin berkurang dengan semakin lamanya imago tidak menemukan inang, jumlah telur yang 
mampu diletakkan $T$. japanicum tidak dipengaruhi oleh lamanya imago tidak menemukan inang, umumnya jumlah telur yang diletakkan lebih banyak daripada jumlah telur dalam ovari setelah perlakuan. Dengan demikian $T$. japonicum memproduksi telur kembali setelah berhasil menemukan inang, hal ini menunjukkan bahwa ketersediaan inang dapat menstimulasi peningkatan produksi telur dalam ovari, seperti yang diungkapkan oleh Drost \& Cardé (1992) bahwa parasitoid dapat menghentikan produksi telur bila inang tidak ada dan menunggu sampai tersedia inang yang cocok sebelum melanjutkan produksi telurnya, serta mengabsorpsi telur bila tidak menemukan inang.

$T$. armigera dan $T$. japonicum meletakkan sebagian besar telurnya pada hari pertama menemukan inang. Hal ini disebabkan karena parasitod umumnya melakukan reproduksi yang cukup tinggi pada awal kehidupannya menjadi imago. Bai \& Smith (1993) menyebutkan pada kondisi inang tidak terbatas, parasitoid melakukan reproduksi yang tinggi pada hari pertama, dan menurun pada hari-hari berikutnya. Buchori et al. (1999) juga mengungkapkan bahwa bagi parasitoid yang berumur pendek, faktor reproduksi di awal kehidupannya menjadi sangat penting, karena di alam bebas faktor mortalitas tidak dapat diduga.

Godfray (1994) dan Quicke (1997) menyebutkan bahwa berdasarkan pola pematangan telur, serangga dapat dibagi dalam tiga golongan, yaitu proovigenik; serangga yang memiliki telur matang pada saat menjadi imago, sinovigenik; serangga yang belum mempunyai telur matang saat menjadi imago dan memproduksi telur selama hidupnya, dan pro-sinovigenik; serangga yang sudah mempunyai telur matang saat menjadi imago dan tetap memproduksinya sampai mati.

$T$. armigera dan $T$. japonicum merupakan parasitoid pro-sinovigenik. Hal ini didukung adanya telur-telur dalam ovari $T$. armigera dan $T$. japonicum sejak kemunculan pertamanya sebagai imago dan terjadinya peningkatan jumlah telur yang diletakkan dari jumlah telur ketika pertama kali menjadi imago yang menunjukkan adanya produksi telur yang masih berlangsung selama hidupya menjadi imago. Fenomena penyerapan kembali terhadap telur dalam ovari karena tidak adanya inang juga ditemukan pada $T$. armigera dan T. japonicum. Hal ini terlihat dari semakin berkurangnya telur dalam ovari sejalan dengan semakin lamanya inang tidak ditemukan. Penyerapan telur ini berpengaruh terhadap lama hidup imago $T$. armigera dan $T$. japonicum. Perlakuan terhadap imago T. armigera yang dibiarkan tanpa inang selama 24 jam, imago hidup lebih lama daripada perlakuan lainnya, hal ini mungkin disebabkan karena imago telah menyerap telur dalam 
jumlah yang cukup banyak sehingga imago dapat bertahan hidup lebih lama.

\section{KESIMPULAN}

$T$. armigera dan $T$. japonicum memiliki telur matang dalam ovarinya pada awal kemunculannya menjadi imago. Perlakuan ketiadaan inang terhadap $T$. armigera selama 3 jam pertama tidak menyebabkan telur dalam ovarinya berkurang, tetapi bertambah. Namun setelah 12 jam tidak menemukan inang, jumlah telur dalam ovarinya berkurang. Demikian juga jumlah telur yang diletakkan meningkat sampai 3 jam pertama walaupun inang tidak ditemukan, dan menurun setelah 12 dan 24 jam tidak menemukan inang. Pemberian inang juga dapat meningkatkan produksi telur $T$. armigera sampai perlakuan 3 jam tanpa inang, namun setelah 12 jam tanpa inang jumlah telur yang diletakkan lebih sedikit dibandingkan dengan jumlah telur dalam ovari setelah perlakuan.

Ketiadaan inang pada imago $T$. japonicum menyebabkan jumlah telur dalam ovarinya menurun. Semakin lama imago tidak menemukan inang jumlah telur dalam ovari semakin sedikit. Pemberian inang dapat merangsang imago $T$. japonicum untuk memproduksi telur kembali. Jumlah telur yang diletakkan tidak berbeda pada setiap perlakuan. Dengan demikian $T$. japonicum tetap efektif sebagai agens hayati dalam pengendalian hayati walaupun inang ditemukan setelah 24 jam dari kemunculannya sebagai imago.

\section{DAFTAR PUSTAKA}

Bai B, Smith SM. 1993. Effect of host aviability on reproduction and survival of the parasitoid wasp Trichogramma minutum. Ecol. Entomol. 18: 279-286.

Buchori D, Hidayat P, Kartosuwondo U, Nurmansyah A, Meilin A. 1999. Dinamika interaksi antara parasitoid Trichogrammatidae dan inangnya: Faktor-faktor yang berpengaruh terhadap kualitas Trichogrammatidae sebagai agens pengendalian hayati. Laporan Akhir Penelitian Tahun Kedua, Hibah Bersaing Perguruan Tinggi VII/2. Institut Pertanian Bogor.

Drost YC, Cardé RT. 1992. Influence of host deprivation on egg load and oviposition behaviour of Brachymeria inntermedia, a parasitoid of gypsy moth. Physiol. Entomol. 17: 230-234.

Godfray. 1994. Parasitoid: Behavioral and evolutionary ecology. New Jersey: Princeton Univ Press.

Li SY, Henderson DE, Myers JH. 1994. Selection of Suitable Trichogramma spesies for potential control of the blackheaded fireworm infesting cranberries. Biol. Cont. nr 4: 2448.

Luck PF, Nunney L, Stouthamer R. 1999. Sex ratio and quality in the culturing of parasitic Hymenoptera: A genetic and evolutionary perspective. In: Bellows TS, Fisher TW, (editors). Handbook of biological control. 
Anis Rohmani et al.,: Pengaruh Ketiadaan Inang

California: Academic Press. p. Quicke DLJ. 1997. Parasitic wasp. 653-672.

London: Chapman \& Hall. 47 